Bangladesh Journal of Bioethics 2020; 11 (1): 35-43

\title{
Justice for Children in Bangladesh: Legal and Ethical Issues
}

\author{
Nahid Ferdousi \\ Professor of Law, School of Social Sciences, Humanities and Languages \\ Bangladesh Open University, Bangladesh \\ Email: ferdousi329@gmail.comm
}

DOI: https://doi.org/10.3329/bioethics.v11i1.49268

\begin{abstract}
Reform of the child justice system has started with the enactment of the Children Act 2013 in Bangladesh. The Act adopted a number of institutional setups for child-friendly justice i.e. child help desks in the police station, separate children's court, child development centres, national child welfare board etc. These all are interlinked and the responsibilities of concerned authorities have been focused on the law. In practice, most of the children are deprived of their fair justice in different phases i.e. police arrest, prosecution, court hearing, and correctional treatment as there is a lack of professional ethics of concerned personnel. Ethical approach, skill, and knowledge of personnel are major challenges for the treatment of offender children. Thus, code of ethics is important for professionals to provide value-based justice for the best interest of the children. The study focuses on the legal and ethical responsibility towards the child justice system in the country to protect child rights and their childhood.
\end{abstract}

Keywords: children, justice, law, ethics, responsibility.

Introduction: Law, ethics, morality and values form an integral part of society. Their combination is required for the protection and justice for the children. The consciousness is reflected in the international legal instruments as well as in the Constitution of Bangladesh to protect children against neglect, cruelty, exploitation and to provide equal opportunities for development. As per the international instruments, the rights for children are the right to be treated with dignity ${ }^{1}$,the right to life $^{2}$, the right to be presumed innocent ${ }^{3}$, prohibition of torture and ill-treatment of children. Accordingly, the government of Bangladesh has been enacted a new legal framework with the commencement of the Children Act 2013 replacing the old Children Act $1974^{4}$ to create a more effective justice for the children best interest.
Child justice is a key component of child rights in terms of upholding their best interests when they involved with crime. The fundamental purpose of children law and child justice system is to control crime, to rehabilitate the children, and establish a fair justice. The Children Act 2013 paves the way for child welfare boards, child-specialized police officers, separate children's court, child development centres, probation officers for the protection and welfare of the children. The age of the children has increased from 16 to 18 in the law. Many of the justice aspects dealt with in the statute are interrelated so the judiciary, law-enforcing agents and other dealing authorities must be sensitized to the provisions of the children's laws. In the justice system, all authorities of the justice system are bound by ethical rules in professional practice. Absence of a separate 
code of ethics, the children did not get improved social services from the judges, prosecutors, investigators and the other related authorities.

The requirements of the concerned agency's ethics and professional responsibilities assist in fair justice for the children. Lack of coordination among related ministries, absence of institutional accountability and regular monitoring system are major barriers to implementing the Children Act, 2013 rightly and also these are hindering the existing legal system. Through many reforms in children's law, children have many different paths of rehabilitation instead of just prison or jail time. But there are many children in the country who are detained for alleged wrongdoing without the protection they are entitled to. Throughout the country, children are charged and sentenced for actions as adults. Most of the law enforcement officials tend to mistreat underage individuals during cases while working through the lens of an adult. Unfair punishments are still handed down domestically, which is definitely a violation of law as well as ethics. It is ethical to allow courts dealing with child offenders to punish them for taking part in illegal activities.

The latest change in children's law attempts to expunge the children's court system. Ever since the establishment of children courts, there has been controversy on the subject of how they should be run and what rules should be applied. As well with more children being tried as adults it weeds out the worst cases; therefore, making the children courts appear more effective. Many children get involved in unsafe activities and it is important that their actions are corrected. Laws regarding children's justice modified many times to assist courts in the rehabilitation of offender children. It is ethical to allow courts to rehabilitate children from unsafe lifestyles ${ }^{5}$.

The ethical and responsible professionals must strive to obey the law and safeguard the best interests of the children, while delivering competent services as a part of the justice system. Professionals like police officers, judges, probation officers and social workers must be committed with requisite skills, knowledge and ethical approach towards the child-oriented treatment of children. However, they must never simply assume this to be an ordinary case. It is the professional's duty to know and understand the legal obligations and responsibilities that apply when children in conflict with the law. Although there is no such code of ethics about treatment toward a child offender, they must treat the children offenders regarding their individual ethical values.

An understanding of children's evolving capacities to make decisions, coupled with knowledge about emotional and social development, is critical to such work. In this context, ethics, values and morality have been playing a phenomenal role in nourishing and building good relations among concerned agencies. An ethical approach is important for all concerned to ensure the fulfillment of children's rights. The study focuses on the legal and ethical issues towards the attitude of dealing authorities for improving the values basis justice system where children can enjoy their basic human rights. 
Method: The study was mainly qualitative in nature. It is designed mainly based on the existing laws relating to child protection and justice in Bangladesh. Necessary data are collected from secondary sources. Secondary data have been collected from different sources such as reading materials, journals, research articles, the internet, leading cases, international conventions, government statistics and so on.

\section{Legal Framework for Child Protection:}

Bangladesh has separate children laws that are applicable to establish different types of care and protection services for the offender children. The Children Act provides safeguards for the protection of children who come to contact with it as victims, witnesses, and offenders and focuses specialized system with a child's dignity, age, gender, incapacities, maturity and so on. The concerned ministries are drafting the different laws on victim-witness protection, children's rules and children's policy for further activation of the justice system. It requires to mention here that after the ratification of the UNCRC 1989, the laws regarding children's justice were not consolidated in Bangladesh. Most of the children are deprived from proper protection of their rights under the laws and usually they received the same treatment as the adults in the criminal justice proceedings. Consequently, children lost their childhood as they suffered adversely in the criminal justice system.

Major Changes of the Law: In Bangladesh, the Act 2013 defines a child as anyone up to the age of 18 years while the age of children was 16 years in the Act 1974 and only for age disparity with international norms children did not get access to fair justice ${ }^{6}$. As per international instruments children are entitled the exclusive rights to get justice on the basis of their age, maturity into essential circumstances and needs. However, the Act 2013 introduces a new provision regarding children age, specialized children courts, certified correctional institutions, probation service, diversion and alternative sentencing.

Bangladesh introduced the right-based approach by the Act 2013 for the protection and wellbeing of the children. The law prohibits to arrest the children under the age of 9 years. If any child above age 9 is arrested, the use of handcuff and ropes are completely forbidden in the law. Moreover, the law covers many aspects of children's vulnerability in detention stages such as, the new provisions regarding the child affairs police officer who maintains separate treatment of the offender children ${ }^{7}$. It prescribes the duties of the police officer such as contacting probation officer, informing parents and family members, and exploring appropriate diversion programs for justice involved children upon instruction from the children court ${ }^{8}$.

Looking at the concept of children court, three juvenile courts were established under the Act 1974 in Bangladesh but the Act 2013 requires that at least one children court be established in each district headquarter and metropolitan areas, which has the exclusive jurisdiction to deal with juvenile offenders ${ }^{9}$. The children court has the responsibility for the assessment and determination of age of 
the delinquent children ${ }^{10}$. The law strictly prohibits the joint trial and the trail shall be completed within 360 days from the day of the child's first appearance before the court.

Another angle of institutional service in the country, the Act2013 provides more comprehensive outlines for the establishment of certification and operational producers of child development centers as correctional institutions ${ }^{11}$. The three correctional centers along with juvenile court has been established under the Act 1974. Later, the Act 2013prescribes to establish and maintain a necessary number of child development centers or certified institutions for both male and female children ${ }^{12}$. Additionally, the Act 2013 elaborately focuses the provision of probation officer with the appointment, responsibilities and duties for ensuring probation service in the centers ${ }^{13}$. As per the law probation officer has important responsibilities in the time of arrest, trial and field inquiry of the children case ${ }^{14}$. The officer prepares and preserve a separate file for each detained child to follow the procedure for alternative care ${ }^{15}$.

To extent the wellbeing services, the Act2013 includes the provision of a child welfare board for monitoring the child development centers and certified institutes. The law prescribes the appointments, roles and activities of the board in detail. The main responsibilities of the board are to supervise and evaluate the activities of child development centers, provide guidelines for rehabilitation and reintegration, and review the development and implementation of all programs related to offender children. The board with the probation officer is responsible for finding out suitable alternative care and ensuring the children's best interest ${ }^{16}$. The national level board are only entitled to provide guidance and instruction. Other district and city level boards can enforce the supervisory power and it would be played an important role for reducing delinquency ${ }^{17}$.

Regarding the punishment of children, the Act 2013 moderated the punishment system of the offender children in line with international conventions in Bangladesh. As per the law children shall not be sentenced to death or imprisonment for life. The duration of the penalty of the children would not exceed the maximum period rather children can be detained in child development centers instead of jail until the age of 18 . The law strongly is forbidden to detain children with adults in prison ${ }^{18}$. So, the law allows the imprisonment of the children for extreme cases is really uniformity with the international standards.

The concepts of diversion and any types of alternative measures were not recognized in the 1974 Act, so the Act 2013 introduced the provision for a diversion program, family conferencing, restorative justice and alternative dispute resolution ${ }^{19}$. The Department of Social Service is mandated to design and implement diversion programs and cannot be used as legal document in court proceedings ${ }^{20}$. Both probation and police officer are assigned to take necessary steps to arrange this program for reformation of the detained children ${ }^{21}$. 
A drawback of the Legal Issues on Child Justice

Absence of Children Rule: The Act 2013 recognizes some administrative authorities and mentions their responsibilities for establishing a child-oriented justice system ${ }^{22}$. At present lack of Children Rules ${ }^{23}$ these provisions of the Act 2013 yet to be implemented fully with child-friendly police desk, adequate number of probation officers, and child welfare boards. The child welfare board or the probation officer shall determine the most suitable alternative care for the child, taking into consideration for the best interest of the delinquent children ${ }^{24}$. The district or sub-district child welfare board shall review the information received and shall make recommendations to the concerned authority for the overall welfare of the child ${ }^{25}$. But there is no specific guideline or definite rule that how the methods would be applied or how alternative interventions would be conducted in the ground. However, district and sub-district level Boards do not have any functions dealing directly with offender children, despite having a mandate to inspect prisons, making their role in regard to these children unclear ${ }^{26}$. This is completely an ethical issue to deal with children welfare. In this context, establishment of child affairs police desk, child welfare board, family conferencing and other diversion programs seem to be most challenging tasks ${ }^{27}$.

Insufficient Supportive Key Actors:The most significant components of child justice are the child affairs police officers and child development centres (CDCs) with adequate probation officers. The Act 2013 requires every police station to maintain a child affairs desk and to have a $\mathrm{CAPO}^{28}$ in that desk, till adequate child affairs desk has been set up. Rather it is often published in newspapers that children below the age of accruing criminal responsibility are being arrested by the police officers and detained with the adults. Additionally, Child Development Centres (CDCs) is clearly inadequate and as a result the child offenders therein do not have regular communication with their parents. There are at present only three CDCs and no other CDCs or rehabilitation center for the development of child offenders in the country. Lack of CDCs, the rights of the children is continuously being violated once they are kept in prisons ${ }^{29}$. It is clear that reformed Act 2013 has been in effect in Bangladesh for almost eight years now, key actors in charge of child justice (i.e., police officers, probation officers and judges) still lack clear understanding of child rights laws.

Since there are only three specialized institutes for children correction under the Act1974and there are no child development centers established under the Act 2013yet. The law prescribes the provision relating probation officers ${ }^{30}$ who are prepare and preserve, a separate file for each child in child development centers and follow the procedure for alternative care of offender children ${ }^{31}$. The probation officer is also responsible to submit the social enquiry report about the offender children in the court as prescribed by the children rules ${ }^{32}$. The main problem is that there is no children rules and updated probation offenders' law in the country rather the service has been executed 
by the Probation of Offenders Ordinance 1960.

Limited Children Court: Presently, except the three special children courts, there are no separate children courts which could ensure that children are separated and treated differently from the adults at all stages of the criminal proceedings ${ }^{33}$. As per the Act 2013, the children court will arrange for proper seating arrangements for the child and will provide special arrangements for challenged child, where necessary ${ }^{34}$. From 2014, the additional session judge court is performing responsibilities and working as a children's court in each district and metropolitan area in the country. Although, the additional sessions judges have been empowered as the children's court within their own respective jurisdictions, but the additional session judge court are arguably the busiest criminal courts in the country and therefore, either a children's court exclusively dealing with child offenders should be established or a less busy should be empowered as children's court for ensuring children justice.

Although the Act 2013 has brought a massive change in the field of child justice the childoriented specialized justice units have not been established in Bangladesh. Due to the functional structure and resource constraints, law enforcement agencies, courts, and child development centers are not able to provide adequate services that reflect the interests of the juvenile. The law documented the functioning of specific children courts as one in each district but except for three children courts in the centers, the separate children courts have not been established yet.
Thereafter, the Ministry Law Justice and Parliamentary Affairs determined by a gazette notification that the additional session judges court will be empowered as a children court $^{35}$.

It requires note that the Act 2013, further has been amended in 2018 to expand the children's courts. The Act2018 (amended) contains the provision of establishing the children tribunals in each district. At present all tribunals of the women and children repression prevention are working as children tribunals for the operating trail procedure of children offenses. The majority of the children cases are tried by the criminal courts where no special procedure is followed which are mentioned in the Act 2013. Even the modernized judicial process is not nearby due to not having separate courts and specialized child-friendly courtroom ${ }^{36}$. In this regard, either the criminal court environment should be changed or the trial should be held in these separate courts which are made especially for juveniles.

After reforms of child justice law, lack of proper implementation of the Act 2013, creates many limitations among key actors in the justice administration. Consequently, most of the children are not getting proper services from the dealing authorities. There are not enough resources in CDCs to develop into meaningful service for protecting the rights of a child offender. That's why protecting the rights of offender children is a major challenge in Bangladesh 37 . Consequently, a large number of children are subjected to physical, verbal, humiliating, and threatening by the concerned agencies. 
The underlying factors influencing offender children include low family income, social insecurity, inadequate awareness and reluctance of the duty bearers, poor institutional capacities for child protection. However, the above situations demand a national code of ethics regarding core values of authorities in child justice system.

However, to reduce the detained children the child affairs police desk should be launched in all police stations. When new concepts are fully in place, fewer children cases will need to go to court. In the meantime, these desks have been already set up in some police stations in divisional levels and more are in the process. Additionally, independent national child welfare boards should be set up in each district for monitoring the condition of the physical, social, and mental development of the detained children. These institutions all together are able to implement the provisions of alternative care and diversions of the children. However, there are no children rules on how methods of diversions would be practiced in the ground. Thus, Bangladesh should act proactively to make the necessary children rules in line with international guidelines ${ }^{38}$.

\section{Ethical Issues of Concerned Authorities:} Child justice system comprises the set of laws, policies, regulations, and services needed across all social sectors especially social welfare, education, health, security, and justice to support prevention and response to protection-related risks ${ }^{39}$ In this context, ethical guideline is important part to build social relations and growth of society especially in the justice for children ${ }^{40}$. It is obligatory for all dealing authorities to be at least familiar with and preferably conversant with the ethical guidelines. Identifying responsibilities in laws is essential to address most of the children rights issues as they directly deal with children and the societies, they live in. it is crucial to protect children's rights, active participation from the individual, family, community and society as a whole along with the processes of law ${ }^{41}$.

Often lack of professional ethics of police officers shows their rough attitude when they arrest offender children. Most of the children do not receive a child-friendly approach from child development centres. Moreover, the session court's environment and the trial procedure are not appropriate for the children dealing. Within the children justice system, ethics is relevant to most management and policy decisions relating to punishment. Hence, the part of the justice system that addresses the provision of protection of children should include ethics systems.

In Bangladesh, a set of national standards for the protection of children has been developed to set the framework for the administration of child justice. Ethical standards are highly important for the country to provide valuebased treatment of child offenders in all stages of justice. Equally, the development of the code of ethics in the legal system is most needed and for that there is no other alternative but raising the knowledge of professional responsibility, legal accountability, and judicial professionals with regard to ethics ${ }^{42}$.

In practice, child justice authorities are facing variety of dilemmas in the course of their career. Some will be personal, some will be social, and others will be legal. None of these 
is necessarily an ethical dilemma. A child welfare authority should remember that they are accountable for their actions to the law and court. Many of the duties of concerned authorities are imposed either by law or by court order. One should certainly consider that one has a responsibility to follow those duties. However, not everything legal is necessarily ethical ${ }^{43}$. The persons who are working with offender children have a responsibility for providing fair service to the children in their care and protection. They have also some responsibilities towards their immediate colleagues and other professionals with whom they need to collaborate in the interests.

In this situation, child justice authorities draw on their knowledge, values, and skills to help children in need and to address social problems. They act honestly and responsibly to promote ethical practices on the part of the organizations with which they are affiliated. Code of ethics should spell out why children and meeting their needs are important, strengthening the motivation of childcare workers to carry out their work effectively and reinforcing their professional values, such as respect, care and concern for the children and families with whom they work. Therefore, ethics is crucial in decisions concerning discretion, force, and due process, because juvenile justice professionals can be tempted to abuse their powers $^{44}$.

Conclusion: Children are the most vulnerable who need special care and protection, especially in their justice system. Over the years, the justice system of the children has gradually improved in Bangladesh but still has a lot to do in this area. While comprehensive laws dealing with issues such as procedures and correctional systems for child offenders are being called by new circumstances. Governmental commitment to fulfill protection rights includes social welfare policies, adequate budgets, public acknowledgment and ratification of international instruments. The stakeholders, the court, the family, the detention facilities and programs, and the community are responsible for the adoption of the new change. A sound child justice system fundamentally requires improved social services, specialized assistance, childcentered initiatives and committed personnel with requisite skills, knowledge and values. Finally, it is highly important to introduce some alternative measures such as, bail, conditional discharge, suspension of sentence, probation, community service, compensation. Modern rehabilitation programs with living guidance can be introduced for the children especially for trauma victims, psychological cases, drug and alcohol addicts to restore the delinquent back to normal living and to develop their personality. It is also important to train up the people associated with the child justice system so that proper implementation of the Children Act 2013 can be ensured. It is highly important for the country to have complete structured rules and regulations on the basis of international principles to provide valuebased treatment of the destitute children in all stages of justice. In terms of child protection and justice, the policymakers, the executives, the academicians, and the civil society should 
put their all effort for an effective juvenile justice system.

\section{References:}

1. The UN Standard Minimum Rules for the Administration of Juvenile Justice (The Beijing Rules) 1985; Rule 13.

2. The UN Convention on the Rights of the Child (UNCRC) 1989; Article 6.

3. The UN Rules for the Protection of Juveniles Deprived of their Liberty1990; Rule 17.

4. The Children Act 2013 (Act no. 26 of 2013).

5. Ferdousi, Nahid, The Establishment of Children's Courts in Bangladesh: From Principle to Practice, Oxford University Commonwealth Law Journal. 2015; 15 (2): 211.

6. The Children Act 2013, sec 4.

7. Ibid.sec 14.

8. Ibid.sec 52(4).

9. Ibid. sec 19 .

10. Ibid., sec 21 (4).

11. Ibid. sec 59-69.

12. Ibid. sec 63 .

13. Ibid. sec 5 .

14. Ibid. sec 6 .

15. Ibid. sec 84 .

16. Ibid.sec 8 .

17. Ibid. sec 9 .

18. Ibid. sec 33 .

19. Ibid. sec 48 .

20. Ali, M Imman,The Children Act 2013: A Commentary by Justice Imman Ali. Dhaka: Penal Reform International and Bangladesh Legal Aid and Services Trust; 2013: 63.

21. The Children Act 2013, sec 37, 38.

22. Ferdousi, Nahid, The Children Act, 2013: A Milestone of Child Protection in Bangladesh, The Daily Star. 24 September 2013: 12.

23. The Children Act, 2013 has authorized the government to frame rules for attaining the objectives of the Act.

24. Ibid. sec 86.

25. Ibid. sec 93 .

26. Ibid. sec 7 .

27. Islam M. R. \& Sikder, M. A. Effectiveness of Legal and Institutional Framework for Juvenile Justice in Bangladesh: A Critical Analysis,Social Research Reports. 2014(26): 66-81.

28. The Children Act 2013, sec 13.

29. Hoque, M Enamul, Best Interest of the Children, Academic Press and Publishers Library, Dhaka. 2009: 18.
30. The Children Act 2013, sec 5.

31. Ibid. sec 84 .

32. Ibid. sec 31.

33. Borhan Uddin Khan \& Muhammad Mahbubur Rahman, Protection of Children in Conflict with the Law in Bangladesh, Dhaka: Save the Children UK 2008: 66-67.

34. The Children Act 2013, sec17 (4).

35. Bangladesh Government official gazette notifications under the Ministry Law Justice and Parliamentary Affairs, 24 April 2014.

36. Hossain, Md. Zakir. Legal Analysis towards Justice for Children, The Daily Sun, 17th March, 2020.

37. Ferdousi, Nahid. The Establishment of Children's Courts in Bangladesh: From Principle to Practice, Oxford University Commonwealth Law Journal, 2015; 15 (2): 197.

38. Ibid. 199.

39. Ali, M. Imman, Towards a Justice Delivery System for Children in Bangladesh: A Guide and Case Law on Children in Conflict with the Law, UNICEF Bangladesh. 2010: 26.

40. Ferdousi, Nahid. "The Children Act, 2013: A Milestone of Child Protection in Bangladesh", The Daily Star, 24 September; 2013: 12.

41. Muncie,John. The United Nations Children's Rights and Juvenile Justice, Youth Justice Handbook: Theory, policy and practice, Cullompton: Willan; 2009: 20-21.

42. Ferdousi, Nahid, Legislative Action for Protection of Juvenile Offenders in Malaysia and Bangladesh: An Overview, Journal of Malaysian and Comparative Law.2014; 41(1): 125 - 140.

43. Miah, Md. Abdul Kader, Akter, Mahmuda \& Kamruzzaman Md. The Effectiveness of Restorative Justice Practice in Bangladesh: An Analysis, Humanities and Social Sciences. 2017; 5 (5): 176-183.

44. Islam, M. Rezaul and Sikder, Md. Anwarul Islam. Effectiveness of Legal and Institutional Framework for Juvenile Justice in Bangladesh: A Critical Analysis. Social Research Reports. 2014;26: 66-81.

Author Contributions: Authorconceived the idea, literature review and wrote the manuscript. She checked the manuscript meticulously.

Conflict of interests: The authors declare no conflict of interest in this study. 
Bangladesh Journal of Bioethics 2020; 11 (1): 35-43 